\author{
CAMILLA JALVING OG MARIE LAURBERG \\ Mag.art. og ph.d., museumsinspektør på ARKEN Museum for Moderne Kunst \\ Mag.art., museumsinspektør på ARKEN Museum for \\ Moderne Kunst med speciale i samtidskunst
}

\title{
PERFORMATIVE UTOPIER I SAMTIDSKUNSTEN
}

\begin{abstract}
PERFORMATIVE UTOPIAS IN CONTEMPORARY ART | The article deals with the current interest in the notion of utopia within contemporary visual art and theory. It is argued that utopia as a concept and area of investigation has returned on the contemporary art scene, albeit in a remarkably new way. If modernism presented utopia as a final vision for a better society, utopia is now articulated in a less ambitious way, in the vein of the much more modest question "what if"? Basing its argument on art projects by Andrea Zittel, Olafur Eliasson, Francis Alÿs and Tomàs Saraceno among others, the article puts forward the notion of a "performative utopia" - a utopia that is enacted rather than represented, and which is thus contextually and situationally defined. In the article the notion of a performative utopia is related to Nicolas Bourriaud's idea of the "microutopia" and Fredric Jameson's distinction between utopia as program and impulse. In conclusion it is stated that in as much as the contemporary utopia does not necessarily describe a fixed reality, its main objective is to project new visions. Hence, its criticality is not descriptively based, but lies in its ability to present a counter-image that calls on the imagination of the viewer. A plea is made for this kind of criticality as it is argued that

challenging the boundaries of our imagination in itself constitutes a true cultural transformation.
\end{abstract}

KEYWORDS | contemporary art, utopia, modernism, performativity

En fornyet interesse for utopien er dukket op som en markant tendens i det seneste årtis kunst og kunstkritik. I kontrast til billedet af en postutopisk tilstand, som prægede kunsten i I980'erne, baserer et stort antal udstillinger, publikationer og kunstprojekter sig på utopiske modeller eller refererer direkte til utopien på en måde, der ville have været utænkelig blot årtiet inden. ${ }^{2}$ Det vil være denne artikels påstand, at samtidskunsten generelt betragtet ofte berører utopien som dynamisk drivkraft for kunsten, men den viderefører ikke de forestillinger om kunsten som bebuder af radikal social forandring, der igennem det moderne blev associeret med

I Dele af dette essay har tidligere været publiceret i artikler relateret til det treårige Utopia-projekt på ARKEN Museum for Moderne Kunst (2009-II): Jalving 2012 og Laurberg 20I2. Der henvises i øvrigt til publikationen Jalving, Høholt og Gether: Utopic Curating, ARKEN Bulletin nr. 5, ARKEN, 2010.

2 Man kan her nævne udgivelser som Michael Fehr, Thomas W. Rieger og Jörn Rusen (Red.). Thinking Utopia: Steps into Other Worlds. New York \& Oxford: Berghahn Books, 2005; Richard Noble (Red.). Utopias. MIT Press \& Whitechapel Art Gallery, 2009; og Meyer. 
utopibegrebet. Utopien har med andre ord fortsat betydning inden for samtidskunsten, men vel at mærke på en ny måde. Ikke som en færdig udformet vision for et bedre samfund, formuleret i eller realiseret gennem kunsten; men som en tro på, at kunsten kan inspirere os til at tænke ud over det eksisterende - mod bedre måder at leve på. Når kunstnere udforsker utopiens potentiale i dag, sker det således i et felt og på en måde, der ligger hinsides modernismens ideologiske universalløsninger såvel som postmodernismens angreb på de store fortællinger. I dette felt er utopien udtryk for den lokale og individuelt baserede forestillingskraft, hvis verdensforandrende potentiale synes at kunne rummes i et lavmælt spørgende "hvad nu hvis?".

Dette betyder imidlertid ikke, at samtidskunstens kritik af modernismens programmatiske utopier er glemt. Særligt associationen med de totalitære ideologier, der op gennem det 20. århundrede realiserede deres samfundsvisioner i en serie af diktaturer og menneskelige katastrofer, har bidraget til en berettiget skepsis over for de forestillinger om en totalløsning på samfundets problemer, som også prægede periodens kunst. I slutningen af århundredet var en stor del af de drømme, som drev sådanne forestillinger, skudt i sænk, hvilket efterlod et tomrum dér, hvor ideer om universel sandhed, historisk fremdrift og forestillinger om det sande og det gode før kunne formuleres med en vis optimisme. Som den amerikanske utopiforsker Rachel Weiss skriver, synes en af de givne præmisser, da postmodernistiske kulturkritikere gjorde status mod slutningen af det 20. århundrede, ikke blot at være historiens afslutning, men overbevisningen om, at utopiske ideer altid er latterlige eller farlige, idet hun understreger, at "det er dette problematiske fundament, som enhver idé om utopia i dag må basere sig på” (Weiss I9I). 3

Bevidstheden om, at utopien bærer på denne problematiske arv, skinner tydeligt igennem, når såvel kunstnere som kritikere de seneste år har nærmet sig den. For mindst lige så påfaldende, som selve antallet af disse nye projekter er, er den sikkerhed, hvormed genintroduktionen af utopien altid i samme åndedrag følges af kommentarer, der skal moderere forestillingen om, hvad utopien er eller kan være.

\section{Mikro-utopien}

En af de nok mest kendte reformuleringer af utopibegrebet i den nyere kunstkritik finder man hos den franske kritiker Nicolas Bourriaud. I sin bog Relationel Æstetik fra 1998 introducerer Bourriaud blandt andet begrebet 'mikro-utopien', som han ser som samtidskunstens modsvar til modernismens heroiske fremtidsdrømme

3 Denne diskurs om utopiens død eksisterer stadig i dag. Se for eksempel Booker. Med reference til Fredric Jamesons teorier om det postmoderne beskriver Booker en "post-utopian ethos" i amerikansk kultur; en bremsning af utopiske forestillinger og umuligheden af at projicere reelle alternativer til den nuværende sociale orden - en tilstand, som for Booker (og andre) hidrører fra forbrugskulturens fremvækst i I950'erne og 6o'erne. Forbrugskulturen konstruerer et begær, som nødvendigvis er vedvarende - et individuelt begær efter materielle goder, som ikke leder til samfundsmæssige forandringer, men derimod fastholder status quo. 
og forestillinger om det perfekte samfund. Begrebet baserer sig på den italienske kunstner Maurizio Cattelans idé om "la dolce utopia". Det sødmefulde - nogle vil hævde det ufarlige - er da også karakteristisk for den utopiforestilling, som Bourriaud bygger op. Som han skriver i Relationel Estetik: "Utopien leves i dag i den subjektive verden, i konkrete og bevidst fragmentariske eksperimenters real time [...] På samme måde søger kunsten ikke længere at fremstille utopier, men at opbygge konkrete rum" (Bourriaud 48-49), eller som han også formulerer det, "sætter værkerne sig ikke længere som mål at udforme nogle imaginære eller utopiske virkeligheder, men derimod at opbygge eksistensformer eller handlingsmodeller inden for den allerede eksisterende virkelighed, uanset hvilken målestok kunstneren har valgt" (I2-I3).

Det er ikke kun inden for kunstkritikken, at man ser reformuleringer af utopibegrebet i løbet af 1990'erne og ind i det nye årtusinde. Også kunstinstitutionerne fremviser en fornyet interesse for utopibegrebet - vel at mærke i den form for aftapning, som i lighed med Bourriauds mikro-utopi stiller sig kritisk an til modernismens totalløsninger. Således viste Museet for Samtidskunst i Oslo i 2003 udstillingen Midlertidige utopier, der netop vægtede samtidsutopiens processuelle karakter, ligesom det mest spektakulære bidrag til Venedig Biennalen i 2003 var udstillingsprojektet Utopia Station, kurateret af Molly Nesbit, Rirkrit Tiravanija og Hans-Ulrich Obrist. Udstillingsprojektet placerede spørgsmålet om utopien lige i hjertet af kunstinstitutionen med et konglomerat af modeller, kunstværker, talks og events af forskellige kunstnere og arkitekter. Selve udstillingsformatet opløste på denne måde ideen om at præsentere én samlet vision for $\mathrm{i}$ stedet at forme sig som et multiperspektivisk og processuelt undersøgelsesrum. At dette var et udtryk for en bevidst strategi, som havde bund i en nyfortolkning af utopibegrebet, blev understreget af de tre kuratorers præsentation af projektet som "intet mere og intet mindre end en mellemstation, et sted at standse op for at se, tale og forny ruten", eller som de også formulerede det: "Selve ideen om Utopia - en idé med en lang historie og mange fastlagte ideologier - har løsnet sig op og er først og fremmest blevet en katalysator eller det ikkested, det altid har været, et håb om en bedre fremtid." 4

Med andre ord, når utopien som begreb dukker op i de seneste ti-femten års kritiske og kuratoriske praksisser, er den ledsaget af en serie af præfikser: Utopien er mikro, blød, lokal og midlertidig. Den er ikke et endemål, men derimod katalysator for noget andet, den er udtryk for et håb eller betegner et ikkested og kan dermed ikke sammenlignes direkte med modernismens "stærke" ideologiske utopier.

\section{Utopi som program og impuls}

Det skifte fra modernismens totalløsninger til nutidens mikro-utopier, som Bourriaud sporer i sin samtids kunst, kan italesættes inden for det teoretiske ramme-

4 Citat fra projektets pressemeddelelse, http://www.e-flux.com/projects/utopia/about.html (sidst besøgt 27.09.I2) 
værk, som den amerikanske kulturteoretiker Fredric Jameson har etableret gennem sin skelnen mellem utopi som program og utopi som impuls. En skelnen som også i denne sammenhæng kan være brugbar, hvis man skal nærme sig karakteren af samtidskunstens utopier. I sin bog Archaeologies of the Future fra 2005 skriver Jameson følgende: "Det er ofte blevet bemærket, at vi bør skelne mellem den utopiske form og det utopiske ønske: mellem den skrevne tekst eller genre og sådan noget som en utopisk impuls, der lader sig spore i hverdagslivet og dets praktisering af en specialiseret hermeneutik eller fortolkningsmetode" (Jameson I). Jamesons betegnelser for disse to kategorier er "program" og "impuls". Under program hører byplanlægning, revolutionær praksis og alternative samfund. Her figurerer utopien som et formuleret ideal. Litteraturen synes at være fuld af sådanne programmatiske utopier, drømmeverdener beskrevet ned i detaljen som i Edward Bellamys Looking Backward: 2000-I887 A.D. fra I888, William Morris' News from Nowhere; or, An Epoch of Rest fra I890, eller H.G. Wells' A Modern Utopia fra 1905. Ligeledes finder man også i byplanlægningens historie, særligt med modernismens totalløsninger som Le Corbusiers byplanlægningsprojekter, eksempelvis det ikkerealiserede Plan Voisin fra 1925, eller Oscar Niemeyers arkitektoniske totaldesign til den brasilianske by Brasilia fra 1956, utopiske visioner af stærk programmatisk karakter.

Utopi som impuls er derimod langt sværere at sætte et entydigt billede på. Jameson opregner politisk teori og reformer på sin liste. Han nævner den enkelte bygning som et modsvar til byplanlægningens masterplan. Men vigtigst i denne sammenhæng er hans påpegning af hermeneutikken, idet han hermed gør utopien til en anskuelsesform frem for et konkret sted, en tankehandling i modsætning til en topografisk lokalitet, "noget der lader sig udpege gennem en specialiseret fortolkningsmetode," som han skriver (4).

Betragter man samtidskunsten gennem Jamesons begrebspar, er det tydeligt, at den vægtning af utopiske programerklæringer, der prægede den historiske avantgarde, i samtidskunsten har forskudt sig i retning af en utopisk impuls. Det vil sige, at utopien netop fremstår mere som en stræben, en gestikuleren mod en alternativ orden eller samfundsmodel, eller mindre ambitiøst, blot en anden måde at være på. Denne stræben, denne utopiske impuls, er også blevet formuleret på anden vis. I den britiske litterat Ruth Levitas' bog The Concept of Utopia fra 1990 får den eksempelvis en ekstra drejning, idet Levitas her introducerer parallelbegrebet "begær" (desire) som en form for grundfigur for den utopiske længsel. Som hun skriver: "Utopiens essens synes at være begæret - begæret efter en anden, en bedre levevis" (Levitas I8I). Med Levitas er vi langt fra utopien defineret som litterær genre, som den stramt planlagte by eller det alternative samfund, som præger modernismens programmatiske utopier. Utopi forstået som begær er en utopi, der hverken kan defineres ud fra form, indhold eller funktion. Den er der blot som det endnu ikke opfyldte ønske om noget andet. Det som endnu ikke er. 


\section{Kunstneriske utopier}

Netop begæret efter en bedre måde at leve eller være på bliver det konkrete omdrejningspunkt for en lang række kunstprojekter fra slutningen af I990'erne og frem til i dag. I 1999 flytter den østrigskfødte kunstner Andrea Zittel til den californiske ørken. I tasken medbringer hun en idé om at skabe "et mere eksperimentalt liv for mig selv” (Cit. i Grögel I9). Midt i ørkenen slår kunstneren sig ned i et selvbygget hus, A-Z West (billede I).

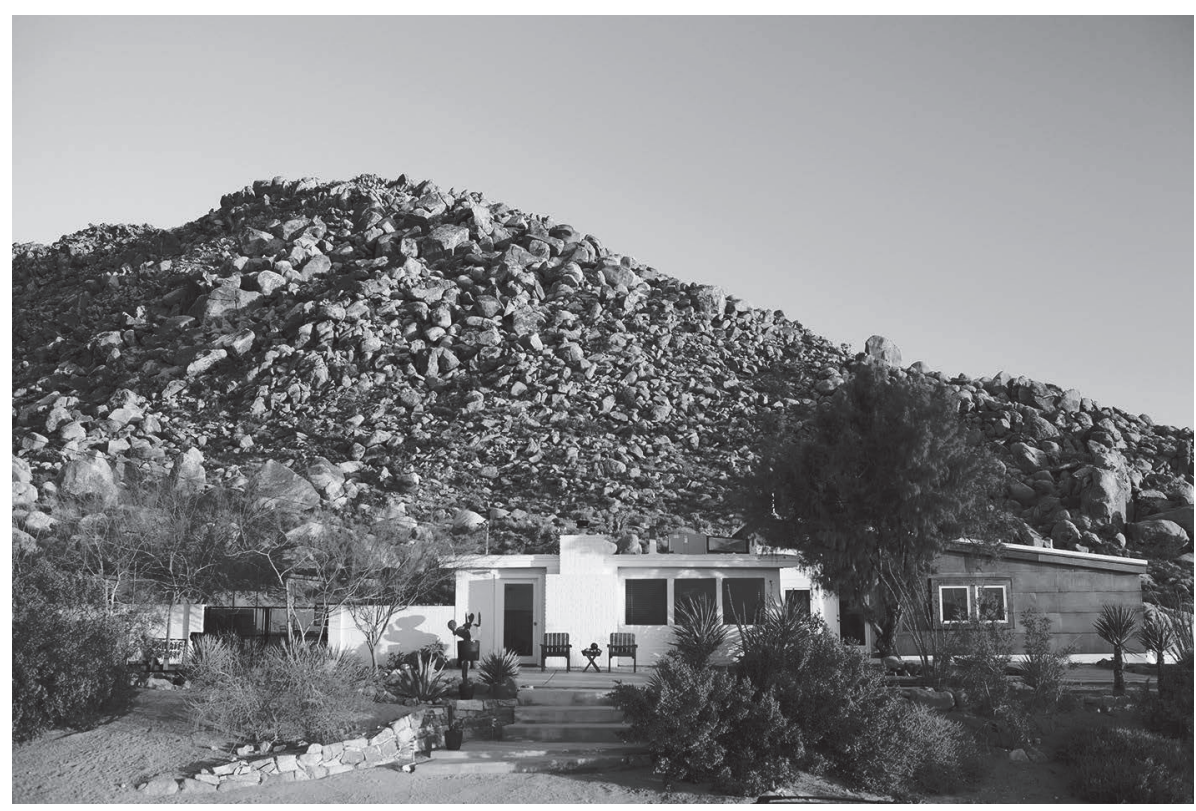

Billede I. Andrea Zittel, A-Z West, studie, 2011. A-Z West er et område på ca. 141.000 m2 i den californiske ørken. Andrea Zittel har skabt et alternativt samfund, som består af et studie, trailers og containere, hvor hende og hendes venner og kollegaer kan arbejde og sove. Det er alt sammen del af hendes $A-Z$ enterprise, som undersøger, hvad mennesker har brug for for at overleve på forskellig vis. Foto af Giovanni Jance. Courtesy kunstneren og Andrea Rosen Gallery, New York.

Dette hus er siden blevet centrum for A-Z Enterprise: "Et institut for undersøgende levevis", der omfatter "alle aspekter af dagliglivet. Møbler, tøj, mad - alt dette bliver til genstand for undersøgelse $\mathrm{i}$ et stadigt forsøg på at forstå menneskets natur og den sociale konstruktion af behov", som man kan læse på kunstnerens hjemmeside. 5 Zittel inviterer løbende andre kunstnere til instituttet for dér at tage del i fællesskabet og bidrage med nye projekter til de mange hektar ørkenområde. Zittel fortsætter på sin vis bestemte organisationsstrukturer og levemåder, som man kender fra forskellige litterære beskrivelser af Utopia. Ligesom Thomas Mores

5 Se www.zittel.org (sidst besøgt 22.03.I2) 
Utopia er A-Z karakteriseret ved at være geografisk isoleret, til en hvis grad selvforsynende og baseret på fællesøkonomi. På den vis synes utopien i Zittels praksis at komme til udtryk på en forholdsvis programmatisk måde, nært forbundet med et specifikt sted, jordstykket i Mojave-ørkenen. Alligevel er der også noget andet på færde. A-Z Enterprise udgør nemlig ikke kun et utopisk sted i Mojave-ørkenen, men vidner også gennem selve den handling at skabe et sådant sted om en utopisk impuls. Et begær efter en anden levemåde, der langt overskrider det specifikke sted, den geografiske lokalitet A-Z West.

I lyset af Zittels meget pragmatiske tilgang til utopien kan man tale om en "bottom-up"-praksis, der som sit udgangspunkt for samfundsopbygning har den enkelte aktørs handlinger og dagligdagspraksis. Utopien defineres ikke ovenfra, men vokser ud af en bestemt form for "væren-i-verden", et sæt af handlinger eller interessefelter, der driver den enkelte. En sådan "bottom-up"-tankegang præger også den dansk/ islandske kunstner Olafur Eliassons praksis. Eliasson, der gerne udtaler sig om sine kunstneriske intentioner, har ofte fremhævet, at brugerinddragelse for ham er et grundprincip. På dette punkt såvel som i den formelle udformning af sine værker har Eliasson et klart afsæt i 1960'ernes minimalistiske kunst, men inddragelsen af brugeren bredes ud fra et fænomenologisk og kropsligt fokus til også at rumme en social dimension. Et eksempel herpå er The collectivity project, som har været udstillet i bl.a. Tirana (2005) og København (2008). Her inviteres publikum til at opbygge deres ideal-by ud af en stor bunke hvide legoklodser. Enhver, der i udstillingsperioden passerer pladsen, hvor værket er udstillet, kan deltage i opbygningen med sit individuelle bidrag. Som et resultat af denne åbne invitation vokser by-visionen nedefra og op i en organisk, knopskydende proces, tilsyneladende uden et specifikt resultat eller endemål. Man kunne næppe forestille sig en større idémæssig modsætning til de idealbyer, som udvikledes af modernismens makroplanlæggere. Eliassons idealby er i stadig forandring og lader sig ikke fæstne i en færdig form. Den er et resultat af brugernes fantasi og vil til enhver tid være et konglomerat af forskellige byvisioner. Og, ganske vigtigt, det er ikke en del af planen, at den på noget tidspunkt skal realiseres som andet end et lokalt eksperiment (billede 2).

Denne "lokalisering" af utopia her og nu effektueredes meget konkret i Eliassons installation Your utopia, som vistes på Venedig Biennalen i 2003. Her præsenteredes publikum for en simpel, hvid vægskulptur med en inviterende rød knap. ${ }^{6}$ Et tryk på knappen udløste et kraftigt lysglimt, hvorefter ordet UTOPIA stod printet fysisk på nethinden som et efterbillede. Med dette direkte, kropslige indgreb måtte hver enkelt besøgende i det efterfølgende tidsforløb se på sine omgivelser med utopia som en flimrende og påtrængende overskrift. Med et simpelt konceptuelt greb transformerer værket utopia fra at være en vision udtænkt af kunstneren selv til at være et spørgsmål rettet mod betragteren. Hvordan ser det gode liv ud? Og hvad kan du gøre her og nu? I en samtale året efter argumenterer Eliasson for at genoverveje utopien som et fænomen, der i modsætning til modernismens

6 Installationen var Eliassons bidrag til projektet Utopia Station. 


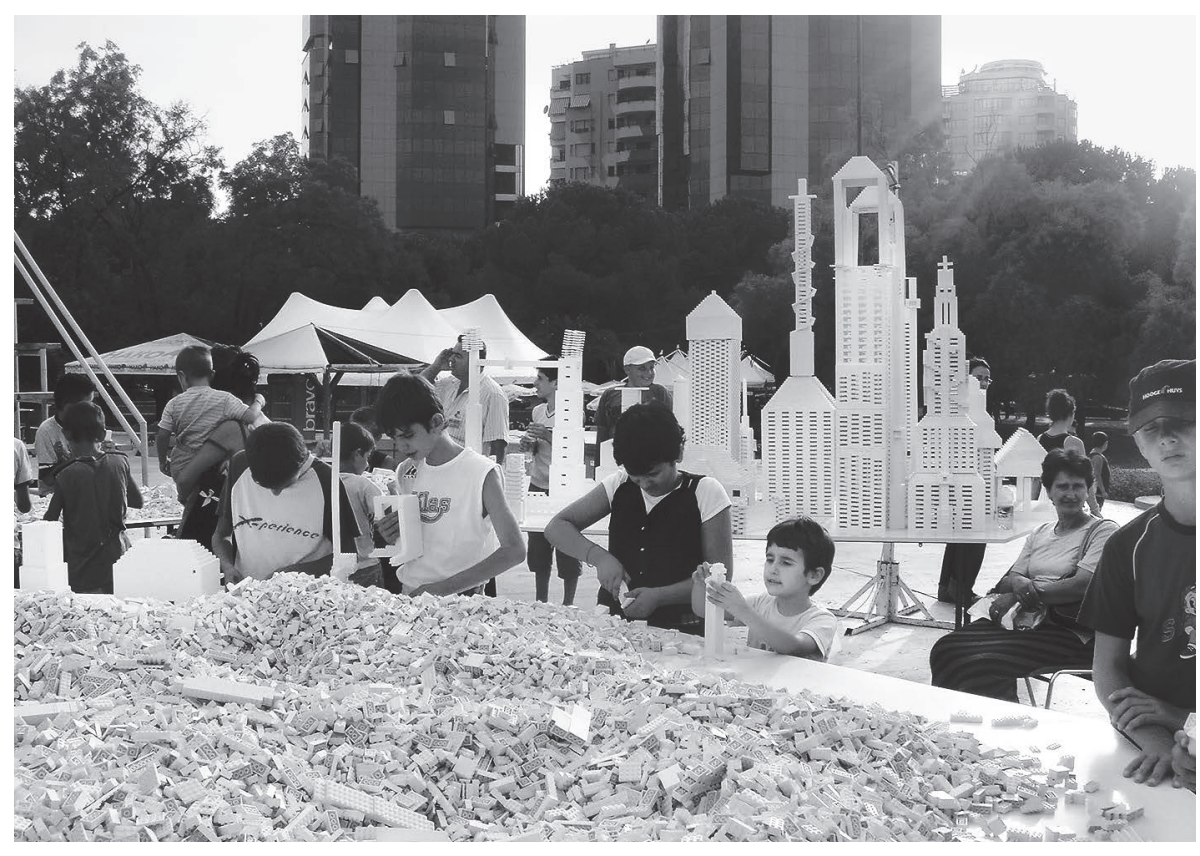

Billede 2. Olafur Eliasson, The Collectivity Project, 2005 . Hvide legoklodser og træ. Variable størrelser. Installation ved 3. Tirana Biennale, Albanien, 2005. Courtesy kunstneren; neugerriemschneider, Berlin; Tanya Bonakdar Gallery, New York.

universelle forestillinger fungerer på et lokalt niveau og giver plads til individuelle ønsker og mål. Som han siger: "Tidligere gjaldt forestillingen om, at Utopia var noget, man projicerede ud på sine omgivelser. Jeg mener derimod, at det er noget inde i én selv; at det er en form for vished, der opstår, når man kan sige: 'Denne situation ønsker jeg at engagere mig i’’ (Cit. i Engberg-Pedersen og Meyhoff 39).

\section{Den performative utopi}

Dette fokus på selve aktiviteten findes hos flere samtidskunstnere, hvor værket udformer sig som en gestus, hvad man kan kalde en performativ kollektiv handling, der fungerer som et mere generelt billede på kollektive drømme og muligheden for forandring. Det performative må her forstås i lighed med den type generativ ytring, der, som den britiske sprogfilosof J.L. Austin har formuleret det, "gør hvad den siger". 7 Frem for at referere til en verden uden for sig selv (i denne kontekst eksempelvis et allerede formuleret idealsamfund) skaber den denne verden i selve fremsigelsen. En

7 Som J.L. Austin har formuleret det, gælder det for en performativ, at det at ytre sætningen "ikke er at beskrive hvad jeg kunne siges at gøre i og med at jeg ytrer mig, eller at erklære at jeg gør det, men faktisk at gøre det” (Austin 37). 
sådan performativ utopi kunne man eksempelvis tilskrive den belgiske kunstner Francis Alÿs, som i sit projekt When Faith Moves Mountains fra 2002 mobiliserede 500 frivillige udstyret med skovle til i fællesskab at flytte et bjerg af sand i ørkenen uden for Lima, Peru. Den egentlige bevægelse var af forsvindende proportioner i det uendelige ørkenlandskab. Hvor meningsløst resultatet end måtte være, får selve handlingen stærk resonans som et billede på fællesskabets mulighed for at gribe ind i omgivelserne. Karakteristisk ligger fokus på selve muligheden for forandring, imens der ikke gives et entydigt bud på, hvad forandringen mere specifikt kunne resultere i.

Eller man kunne fremdrage den argentinskfødte kunstner Tomás Saracenos praksis. Siden 2004 har han eksperimenteret med alternative boformer, der opsendt $i$ atmosfæren $i$ en mulig fremtid kan danne base for menneskers liv, skulle jorden blive ubeboelig. Trods det dystopiske perspektiv, der ligger bag hele projektet, er

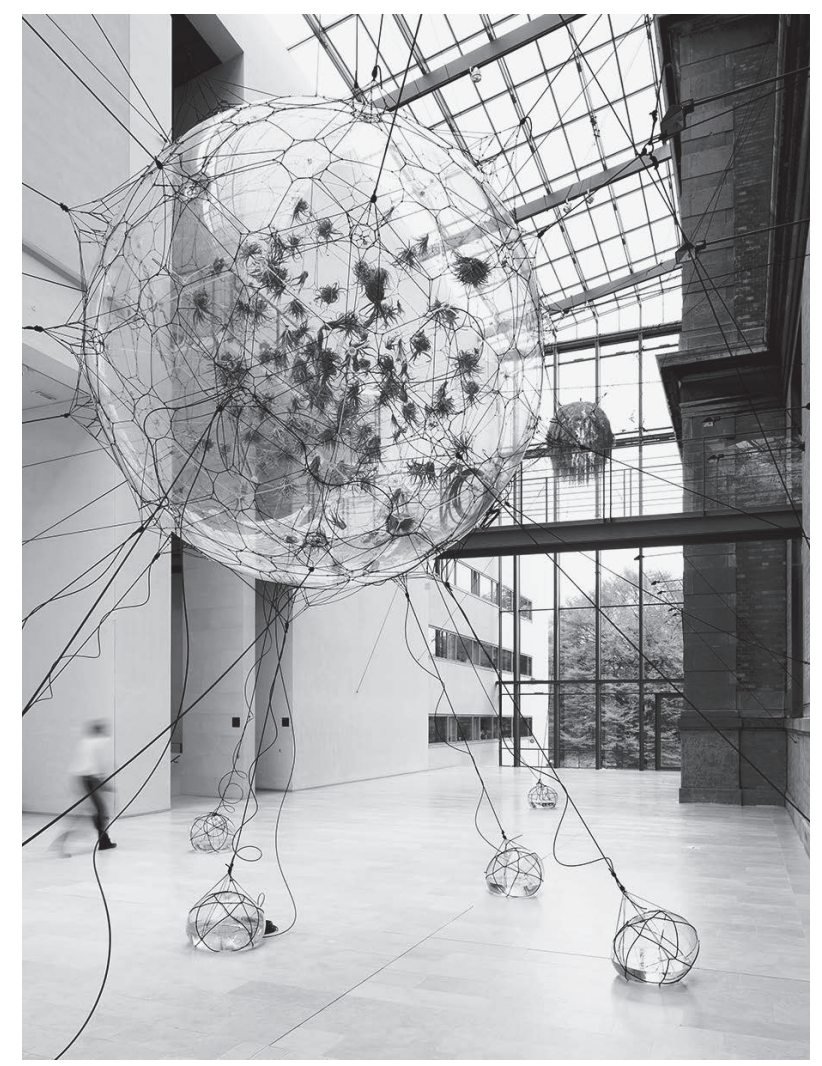

Billede 3. Tomás Saraceno, Biospheres, installation, Statens Museum for Kunst, 2009. Kunstner og arkitekt Tomás Saracenos kunst undersøger visioner om en bedre verden. Hans arbejde befinder sig i grænsefeltet mellem videnskab, kunst og arkitektur, og han arbejder ofte sammen med videnskabsmænd. Drømmen om menneskets mulighed for at bevæge sig frit oppe over skyerne, fri for tyngdekraftens begrænsninger, er et tilbagevendende tema i flere værker. Courtesy kunstneren og Tanya Bonakdar Gallery, New York. 
der både æstetisk og poetisk skønhed at spore i de oppustelige, arkitektoniske strukturer, der i udstillingssammenhænge svæver vægtløse i udstillingsrummet som store sæbebobler (billede 3 ).

Inden i de luftfyldte sfærer eksperimenterer Saraceno på ret konkret vis med lukkede og selvgenererende økosystemer, ligesom han også har samarbejdet med NASA om sine oppustelige strukturer. Således fremstår de som både konkrete og fabulerende bud på en mulig fremtidsversion. De er kunstnerisk forskning og samtidig manifeste udtryk for forestillingskraften. Hvad angår dette sidste, er værkerne på den vis meget mere, end hvad der umiddelbart er synligt i udstillingsrummet. Meget mere end klare bobler med luft og grønne, vildtvoksende økosystemer i. I den optik er det således ikke essentielt, om Saracenos alternative verdener kan bebos, eftersom de gennem selve den performative handling "at gøre det" stadig fremstår som kraftfulde udtryk for en mulig verden og dermed synes at rejse det simple spørgsmål: Hvad nu hvis?

Også den aktivistiske del af samtidskunsten er rig på sådanne performative utopier. En morgen i november 2008 kunne newyorkere i titusindvis således overrasket konstatere, at Irak-krigen var slut. Dette var nemlig forsidehistorien på den gratis særudgave af New York Times, de netop havde fået stukket i hånden (billede 4).

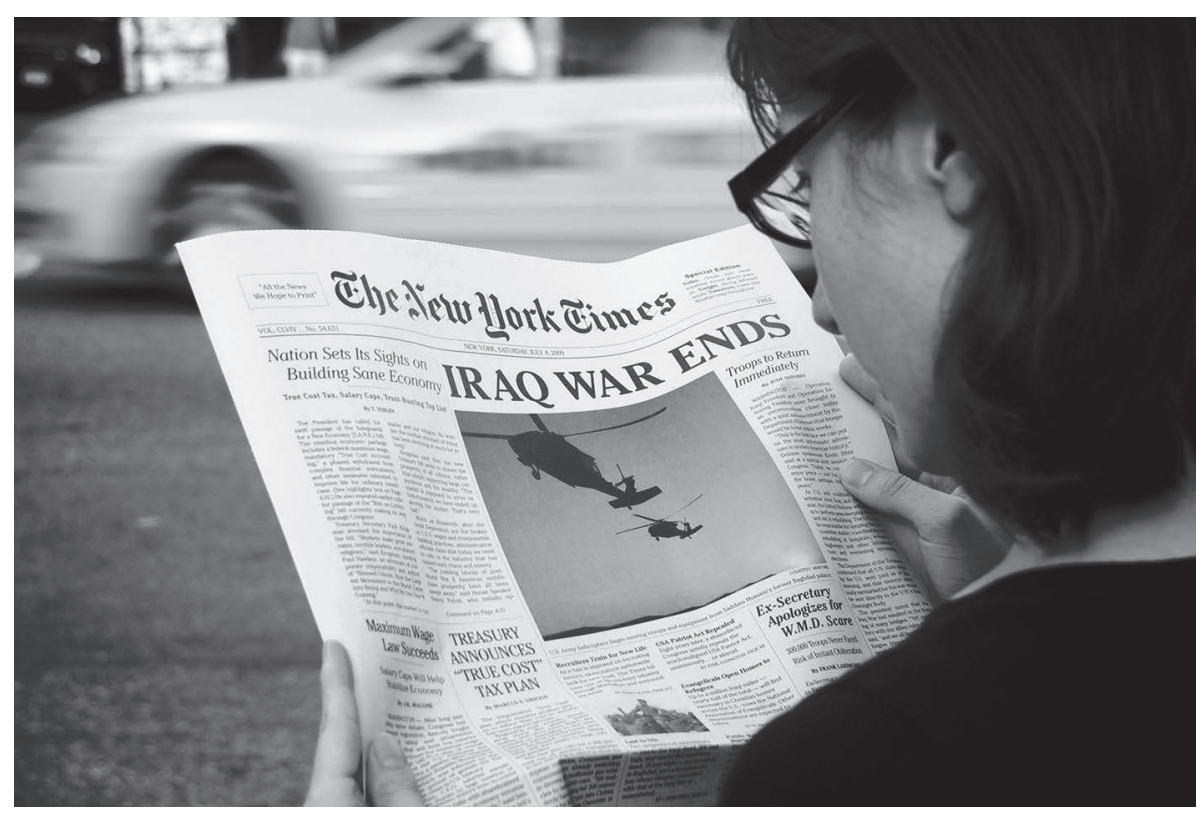

Billede 4. Andy Bichlbaum og Steve Lambert, NY Times Special Edition, 2008. Over 80.000 kopier af NY Times Special Edition blev delt ud i New York d. 12. november, 2008. En fejring/et samarbejde med Steve Lambert, Andy Bichlbaum fra The Yes Men, sammen med 30 andre forfattere, rådgivere, ca. 1000 frivillige distributører, CODEPINK, May First/People Link, Evis Twink, Improv Everywhere og Not An Alternative. Courtesy kunstnerne. 
"Tropperne vender hjem om få uger", lød en underhistorie, ligesom en officiel undskyldning for de falske efterretninger om masseødelæggelsesvåben var blevet udstedt fra højeste sted. Avisen, der blandt mange andre overraskende nyheder også berettede om indførelsen af gratis universitetsuddannelser og en ansvarlig $ø$ konomisk politik, var iværksat af de amerikanske aktivistkunstnere Steve Lambert og Andy Bichlbaum. Avisen havde til lejligheden fået nyt motto: "All the News We Hope to Print". Med lige dele humor og politisk bid blev den trykket i hånden på travle forbipasserende som et håndgribeligt vidnesbyrd om en mulig fremtid (den var dateret 4. juli 2009). For selv om avisen rummede mange humoristiske indslag, såsom en vejrudsigt der lovede "kraftig vind mod venstre", så var den ikke desto mindre virksom i glimtvist at vække en alternativ realitet til live. Som den amerikanske kulturteoretiker og aktivist Stephen Duncombe skriver i en analyse af dette projekt, så byggede det på en omvending af en traditionel venstreorienteret ideologikritik. Frem for "at kritisere verden, som den var, og fortælle folk, hvad der er galt, var avisens formål at skabe et rum, et moment, hvori folk kunne få en følelse af åbne politiske muligheder" (Duncombe 39). Han argumenterer videre, at den humoristiske dimension i denne type kunstnerisk aktivisme (en humor som han i øvrigt sporer helt tilbage til de satiriske elementer hos Thomas More) kan redde utopien fra at forfalde til singulære og autoritative udmeldinger. Som han skriver: "Utopien er ikke en seriøs plan, men den er heller ikke blot en spøg. Den er en tilskyndelse til videre forestillinger hos læseren/betragteren" (44).

Når samtidskunsten på denne måde vækker Utopia til live i en lokal, performativ gestus, tager den tråden op fra 1960'ernes og 70'ernes politiske kunst, hvor satiriske og humoristiske elementer ligeledes skulle appellere til publikums fantasi. Den tidsånd, som kom til udtryk i studenterbevægelsernes slogans som "vær realistisk - forlang det umulige" og "under fortovet findes stranden", genspejledes i billedkunstens poetiske frihedsytringer. Den I. april (!) I973 afholdt Yoko Ono og John Lennon et pressemøde, hvor de annoncerede en ny statsdannelse. ${ }^{8}$ Den konceptuelle stat Nutopia havde hverken jordbesiddelser, grænser eller pas. Dens nationalsang bestod af et par minutters stilhed, og som de to kunstnere demonstrerede på pressemødet, var dens flag et viftende hvidt klæde; selve symbolet på overgivelse. Hvor ophævelsen af grænsedragninger her var rent symbolsk, fungerede den på et mere materielt plan i et af Yoko Onos tidligere projekter, Play it By Trust fra 1966, som efterfølgende er blevet genopført i et utal af performances og interaktive skulpturer. Projektets kerne er et skakspil, hvor samtlige brikker er malet hvide. Efter et par indledende træk må spillerne således opleve, at spillets modstanderforhold såvel som dets underliggende krigsmetaforik ophæves til fordel for en formålsløs ekspressivitet, hvor det at opnå et entydigt resultat og kåre en vinder bliver en umulighed. Med Onos ord opnås fred i en lille skala. Med den kolde krigs opdelte verdensbillede og reelle krigstrussel som sit historiske

8 For en gennemgang af en lang række kunstprojekter, der formulerer konkrete, alternative statsdannelser, henvises der til Dao og Lamunière 20I2. Se desuden Lamunière 2009. 
bagtæppe fik disse projekter - en ny statsdannelse, som straks afskriver sig fra at kæmpe, og et skakspil, som ingen kan vinde - en særlig prægnans som symbolske gestusser. Konfronteret med et forkrampet ideologisk klima opviste de en bevidst, trodsig naivisme, som man genfinder en snert af i samtidskunstens konstruktive optimisme. I hvert fald sporer man i Lambert og Bichlbaums erklæring af Irakkrigens afslutning et ganske kraftigt ekko af Lennons omkvæd "war is over, if you want it" - anno 2008.

\section{Krop og kontekst}

Den konkrete handling er som her beskrevet det vægtigste kendetegn ved den performative utopi. Det er her, den performative utopi adskiller sig fra Jamesons idé om den utopiske impuls. For selv om den performative utopi, som vi her foreslår den, helt grundlæggende bygger på utopien som impuls, rummer dens performative element imidlertid en konkret kropslighed, som ikke lader sig beskrive som blot og bar impuls. Denne kropslighed er ikke abstrakt som tanken eller forestillingsevnen, men handler som i de nævnte værker om for eksempel at bosætte sig i ørkenen. Om at bygge et tårn i Lego. Om at flytte skovlfuld efter skovlfuld af sand. Om at skrive, trykke og uddele en fiktiv avis. Den handler med andre ord om at "gøre" noget og gennem denne "gøren" at lade utopien komme ind $i$ verden.

Den konkrete handling er imidlertid ikke det eneste kendetegn ved den performative utopi. Går vi igen til sprogteorien og J.L. Austins grundlæggende ideer om den performative ytring, finder vi ud over denne grundlæggende udpegning af sprogets virkelighedsgenererende kraft en vægtning af ytringens kontekst, afsender og modtagerforhold - hvad man kan betegne som hele talehandlingssituationen. Som Austin beskriver det, er den performative ytring en kontekstbunden ytring, der kun opnår sin betydning og gyldighed i relation til en anden person. Tag eksempelvis et af de mest direkte performativer, "jeg lover". Graden af dette udsagns succes - her vurderer Austin vel at mærke ikke den performative ytring ud fra gængse kriterier om sandt/falsk, men derimod ud fra de mere bøjelige betragtninger som vellykket/ mislykket - afhænger ikke kun af den talendes intentioner og senere overholdelse af dette løfte, men også af modtagerens grundlæggende forståelse af og villighed til at acceptere det sagte som et sådant. Den performative ytring baserer sig i den forstand på en kontrakt mellem udsiger og lytter, der er formet af lige dele forventning og konvention. ${ }^{9}$ Overfører man disse tanker til de ideer om den performative utopi, som vi her ønsker at udvikle, må man her hæfte sig ved følgende: Den performative utopi baserer sig på en konkret handling, der er kontekstbestemt og situationsafhængig - både i forhold til afsenderen af værket og modtageren. Hvor et givent værk derfor kan forekomme utopisk gestikulerende for nogen, kan det fremstå som et tomt udsagn for andre. Hvor et værk i en bestemt kontekst, den

9 For mere om Austin og talehandlingsteorien, se Jalving 20 II. 
være sig historisk og/eller kulturel, kan rumme stærke utopiske visioner, kan det i andre situationer fremstå virkningsløst eller blot ligegyldigt. Denne åbenhed, eller situationsbestemthed, er naturligvis en grundpræmis for enhver aflæsningssituation og hermed receptionen af ethvert kulturelt produkt. Ikke desto mindre er det en grundpræmis, som den performative ytring og i et videre perspektiv også den performative utopi sætter på spidsen. Værkets mulige utopi er derfor aldrig for alle, men altid for nogen, aldrig for altid, men derimod til en bestemt tid.

\section{En opfordring til forestillingsevnen}

Nogle kritikere har fortolket denne åbenhed i samtidskunsten som et tegn på manglende kritisk fokus; et udtryk for at kunsten er båret frem af en terapeutisk impuls, som trækker en alt for direkte analogi mellem det mulighedsrum, der åbner sig i kunstens kreative handling, og muligheden for reel samfundsmæssig forandring. ${ }^{10}$ Det kan medgives, at en del af kunstkritikken i ganske betragtelig grad har overgjort analogien mellem kunstens kreative handling og dens potentiale for samfundsmæssig forandring. Men som den amerikanske kunstteoretiker Richard Noble argumenterer for $\mathrm{i}$ en diskussion af sammenhængen mellem politik og samtidskunst: "Forsøget på at modellere en utopisk eller mikro-utopisk mulighed i et kunstværk kan, eller måske $m a ̊$, abstrahere fra de tvangsmæssige vilkår for livet $\mathrm{i}$ dag på måder, der lader det stå åbent, hvad momentet af utopisk mulighed præcist skal kunne tilbyde" (Noble I7).

Hvis man savner en præciseret kritik af sociale og samfundsmæssige forhold i Eliassons brugerinddragende projekter, Zittels beboelseseksperimenter og Saracenos svævende byer, så adresserer man et grundtræk ved utopien. For i kontrast til mere dokumentarisk orienterede udgaver af den politiske kunst, så forholder utopien sig netop ikke deskriptivt. Frem for at analysere den omgivende realitet projicerer den nye visioner. Disse nye visioner rummer naturligvis også deres egen, implicitte kritik. For ved at digte alternativer peger den utopiske kunst mere eller mindre direkte på mangler ved det bestående. Utopiens fantasiforestilling er derfor altid uløseligt knyttet til den historiske kontekst, den er opstået i. For Ernst Bloch er det netop vigtigt, at den utopiske impuls udspringer af følelsen af, at noget ikke er, som det burde være. At "noget mangler", som Bloch har formuleret det med henvisning til Bertolt Brecht (Bloch 15).

Hvad er det så for "mangler" i det bestående, der fungerer som motor for samtidskunsten? I de her diskuterede værker af Eliasson, Zittel, Alÿs, Saraceno m.fl., kan man kun indirekte slutte sig til svaret. Er det manglen på kollektiv fantasi og dialog i det offentlige rum, en konformitet i måden, middelklassen indretter hverdagslivet på, er det urbaniseringens miljøskadelige virkninger? Kritikken er ikke formuleret $i$ selve varket, men fungerer indirekte. Idet værket opstiller et

Io Se f.eks. Bishop 2008, der udfordrer nogle af antagelserne, der ligger til grund for Nicolas Bourriauds Relationel astetik. 
modbillede, vækker det til refleksion, eksempelvis over hvordan man overhovedet bebor noget. Alt efter temperament kan man betragte det som en svaghed eller en styrke, at sådanne spørgsmål overlades til publikum.

Frem for at opfatte samtidskunstens åbenhed som ren og skær uklarhed, kan man også se den som et produkt af den historiske situation, den er produceret i. Idet utopien som nævnt altid er farvet af den kontekst, den opstår i, skal det naturligvis også understreges, at samtidskunstens utopiske dimension tager sig meget forskelligt ud, alt efter hvor man ser hen. Om det er den kinesiske kunstscene, der balancerer på grænsen mellem kommunisme og kapitalisme, den østeuropæiske samtidskunst, som genfortolker arven fra den historiske avantgarde. ${ }^{\text {II }}$ Eller om det - som her - er kunst, der er produceret i Vestens kapitalistiske demokratier.12 Set i denne kontekst kan man fortolke den performative utopi med dens lokaliserede, kontekstafhængige og på sin vis "svage" udmeldinger som udtryk for en bevidsthed om, at man som kunstner i netop denne historiske kontekst ikke kan indtage en position "udenfor". Frem for at videreføre forestillingen om en avantgarde positioneret på historiens yderste forkant forsøger kunstnerne at indkredse et tidssvarende utopibegreb, der netop ikke skal forstås som et autoritativt, singulært udsagn, der kan enten accepteres eller forkastes. I forlængelse heraf kan man argumentere for, at det egentlige anliggende for projekter som dem, der er nævnt her, ikke er at tjene som et konkret eksempel for en social forandring. I stedet gestikulerer de mod forandring som en mulighed. Frem for den nøje beskrivelse af idealstaten eller øen, så kan man sige, at samtidskunsten er optaget af at rette vores opmærksomhed mod horisonten og dermed inspirere os til at tænke ud over status quo.

Dette er en ganske vigtig forskel. For frem for at afvise kunstens urealiserbare utopier som uvederhæftigt dagdrømmeri kan man pege på, at det at udfordre grænserne for vores forestillingsevne faktisk i sig selv udgør en reel, kulturel forandring. For hvis selve ideen om en bare relativt fri fantasi er under beskydning $i$ informationssamfundets varegørelse af vores forestillingsverden, så synes det netop relevant, at kunsten på et mere grundlæggende niveau søger at åbne et nyt rum for imagination. Det er her, samtidskunstens fortsatte insisteren på utopien spiller en afgørende rolle, idet den opfordrer os til at genoverveje, hvad det er muligt at forestille sig; hvad vi overhovedet er i stand til at ønske os. Og dermed lokaliserer den utopien, ikke et andet sted, men lige her.

II For diskussioner af sådanne "lokaliserede" utopier henvises til bidragene af hhv. Rachel Weiss (Cuba), Hou Hanru (Kina) og Inke Arns (Østeuropa) i Laurberg, Høholt og Gether 2012.

I2 For en uddybning af dette set i relation til samtidskunsten og kunstmuseet, se Laurberg 2 OIO. 


\section{LITTERATURLISTE}

Austin, J.L. Ord der virker. København: Gyldendal, I997 (1962).

Bishop, Claire. "The Social Turn - Collaboration and its Discontents". Right About Now - Art ๔

Theory Since the I990s. Red. Margriet Schavemaker og Mischa Rakier. Amsterdam: Valiz, 2008.

Bloch, Ernst. "Something's Missing: A Discussion between Ernst Bloch and Theodor W. Adorno on the Contradictions of Utopian Longing". The Utopian Function of Art and Literature. Cambridge, Mass. \& London: The MIT Press, I996 (I988). I-I7.

Booker, M. Keith. The Post-Utopian Imagination. Westport: Greenwood Press, 2002.

Bourriaud, Nicolas. Relationel Estetik. København: Det Kongelige Danske Kunstakademi, 2005 (1998) Dao, Ildiko og Simon Lamunière. "The Claim for New Territories”. Utopia \& Contemporary Art. Red. Marie Laurberg, Stine Høholt og Christian Gether. Hatje Cantz og ARKEN, 2OI2. I2I-I27.

Duncombe, Stephen. "Imagining No-Place: The Subversive Mechanics of Utopia". Utopia \& Contemporary Art. Red. Marie Laurberg, Stine Høholt og Christian Gether. Hatje Cantz og ARKEN, 20I2. 39-46.

Engberg-Pedersen, Anna og Karsten Wind Meyhoff. At Se Sig Selv Sanse - Samtaler med Olafur Eliasson. København: Informations Forlag, 2004.

Grögel, Katrin. "Andrea Zittel”. Utopics: Systems and Landmarks. Red. Simon Lamunière. Zürich: JRPRingier, 2009. I9.

Jalving, Camilla. Vark som handling: Performativitet, kunst og metode. København: Museum Tusculanums Forlag, 2OII.

Jalving, Camilla. "Utopia in the Eye of the Beholder - A Theoretical Perspective". Utopia \& Contemporary Art. Red. Marie Laurberg, Stine Høholt og Christian Gether. Hatje Cantz og ARKEN, 20I2. 29-36.

Jalving, Camilla, Stine Høholt og Christian Gether (red.). Utopic Curating. ARKEN Bulletin nr. 5, ARKEN, $20 I 0$.

Jameson, Fredric. Archaeologies of the Future: The Desire Called Utopia and Other Science Fictions. London \& New York: Verso, 2005.

Lamunière, Simon (red.). Utopics - Systems and Landmarks. Zürich: JRP-Ringier, 2009.

Laurberg, Marie: "The Museum as Generator - The Utopia Project at ARKEN Museum of Modern Art”. Jalving, Camilla, Stine Høholt og Christian Gether (red.). Utopic Curating. ARKEN Bulletin $n r .5$, ARKEN, 20IO. 4I-53.

Laurberg, Marie. "The Return of the Imaginary - Utopian Impulses in Contemporary Art”. Utopia ๙ Contemporary Art. Red. Marie Laurberg, Stine Høholt og Christian Gether. Hatje Cantz og ARKEN, 20I2. I7-27.

Laurberg, Marie, Stine Høholt og Christian Gether (red.). Utopia \& Contemporary Art. Hatje Cantz og ARKEN, 2012.

Meyer, Siri (red.). Midlertidige Utopier/Temporary Utopias. Oslo: The Museum of Contemporary Art, 2003.

Noble, Richard. "Introduction”. Utopias. Red. Richard Noble. MIT Press/Whitechapel Art Gallery, 2009.

Weiss, Rachel. "Utopiary”. Thinking Utopia - Steps into Other Worlds. Red. Jörn Rusen, Michael Fehr og Thomas W. Rieger. New York/Oxford: Berghahn Books, 2005. 